\title{
Julien Benda's Thoughtful Europe
}

Perhaps one of the most passionate pleas for the unification of Europe, Julien Benda's Discours à la nation européenne, ${ }^{1}$ published in 1933, has not figured in recent political and philosophical discussions on Europe. A contemporary audience will find his words at the same time prophetic and outmoded. Prophetic, because his defence of the ideal of a supranational Europe as the incarnation of reason, at a time when Hitler was about to come to power, sounds like a manifesto for a kind of rational polity which was to be envisaged only decades later. Outmoded, because, in spite of his lucidity about the threat of Hitlerism, his defence of the European ideal has overtones of the defunct Sociéte des Nations and bears the mark of a pre-war context which is utterly different from our own. Moreover, why read such works, which enjoin us to make Europe? Has it not been 'made' already, for better or for worse?

Benda's Discourse is a sequel to The Betrayal of Intellectuals, ${ }_{2}^{2}$ a book which owes most of its success to its title: everyone admits that the 'intellectuals' have 'betrayed', although not everyone agrees on what betrayal they have committed. Benda argues that the 'clerks', those whose actual destiny is that of an entire devotion to truth, have betrayed their ideals in making practical and political success the only criterion of intellectual value, and in accepting the dictates of feeling and sentiment instead of those of reason. Nationalism, mostly French and German, which he had fought during the Dreyfus affair and the First World War, was Benda's primary target. His other target was what he called the empire of passion over reason, which he associated closely to the nationalistic passion. Benda's Europe is a Platonic Idea, which is the object of a purely spiritual love, and which exists absolutely apart from the sensory order to which the nations belong. When Benda calls for a moral reform, what he is asking from the Europeans is a real asceticism, which would bring them from the realm of feeling to the pure world of intellect:

"Julien Benda's Thoughtful Europe" by Pascal Engel,

The Monist, vol. 92, no. 2, pp. 315-321. Copyright @ 2009, THE MONIST, Peru, Illinois 61354. 
Nations will have been beautiful Clorinds, happy to be sensible objects of carnal love. Europe will have to look like this young woman scientist of the XIIIth century who taught mathematics in the University of Bologna and who appeared with a veil before her audiences in order not to cause trouble in them through her beauty. (Discours, p. 50)

Benda's vibrant defence of Europe is not, however, without ambiguities. It is not clear that what he proposes is a process of unification which would overcome the model of the nation state and that he rejects any kind of nationalism whatsoever. On the one hand, he urges us to reject the nation-state, and to build Europe into a kind of unity that is totally alien to the nation:

Clerks of all countries, you must be those who proclaim to your nations that they are perpetually in evil, just because they are nations. [...] Europe, if it is really to be made, will require the advent of a European soul which will dominate, and in a large part will damp the national souls. (Discours, p. 85)

On the other hand, his title parodies Fichte's Reden an die Deutsche Nation, and he suggests that Europe might be a super-nation which will be the product of the same kind of unification as those which produced the French Republic and Germany:

Europe will be made, here, in the way the nation was made. France was made because, in each of the French, his love for his field or his province was replaced by his love for a reality transcendent to these crude tangible things. It is by fixing their eyes upon the idea of France that the French have rebuilt their nation each time when, in the sentient order, it was dismantled: under the feudal divisions, under the English invasion, under the religious wars, when it was torn apart by the Revolution. (Discours, p. 19)

Benda is not addressing humanity in general, but only European humanity. His model is not the Stoic and Kantian ideal of cosmopolitism, but a form of European cosmopolitism, from which America, in particular, is excluded. Although he seems clearly opposed to Ernest Renan, who, in his famous lecture "What is a nation?" (1882) defined it as a "spiritual principle," his address to the European nation does not invoke an idea of pure reason, in Kant's sense, but rather what he calls a mystique. In a sort of Humean move, Benda admits that reason in itself has never produced anything in the world of feeling and that it has to be the slave of the passions. Addressing future European clerks, he says: 
The point is not for you to oppose pure reason to nationalistic "pragmatism"; pure truth to idols. Pure reason has never founded anything in the earthly order. The point is to oppose to pragmatistic nationalism another form of pragmatism, to myths other myths, to a mystique another mystique. Your function is to make gods. Just the contrary of science. You have to be apostles, the contrary of scientists. You will win against the nationalistic passion only through another passion. This may well be the passion of reason. But the passion of reason is a passion, and something different from reason. (Discours, pp. 20-21)

In other words, although Benda recommends for the clerk a purely spiritual activity and a retirement to the ivory tower, he admits that reason alone cannot move us and considers that the promotion of the European ideal cannot be made on purely intellectual grounds. But the form of political realisation to which this mystique of European universalism leads is not clear. Is Benda proposing for the political organisation of the future European state the very model of the nation state? He actually never advances any principle for a political organisation of Europe. His politics seem to be purely voluntaristic. The very idea of Europe is more the object of a pure act of the will than a concept that could be defined:

You will make Europe through what you will say, not through what you will be. Europe will be a product of your spirit, of the will of your spirit, not a product of your being. And if you answer that you do not believe in the autonomy of your spirit, that your spirit is but an aspect of your being, then I declare to you that you will never make Europe. For there is no European being. (Discours, p. 67)

It is certainly ironic that Benda, who had presented himself before and after the First World War as one of the sternest critics of Bergsonism as a philosophy of 'mobility' and as a religion of action, ${ }^{3}$ when he speaks about Europe echoes the very voluntarism that he had criticized.

The same sort of tensions affects Benda's 'solution' to the problem of Europe's common language. He reminds us that his Europe only existed in medieval times when the lingua franca of the learned was Latin, and he castigates the humanists for having returned to the national languages. But Benda argues that, since Europe is a rational ideal, the language of Europe has to be the language of reason, and that the language of reason has to be the French language, because, as he tells us, it is "the clearest" and "the one which has the least number of idiosyncrasies." Here 
Benda clearly opposes Hegel, who said that Luther would never have accomplished the Reformation if he had not translated the Bible into German. But at the same time his defence of the French language is hardly without nationalistic overtones and echoes Rivarol's De l'universalité de la langue française. ${ }^{4}$

If we suspend for one moment the suspicion that Benda might be defending a French Europe, hence a particularised universal, and not Europe as a universal, his Europe has all the virtues and all the defects of Platonist politics. Since Europe is for him an abstract idea and a separate universal, it does not need to be instantiated in specific institutions or in any region of space. At no point does he raise the issue of the geographical limits of Europe, and although nothing in his principles would prevent a Turkish clerk to espouse his universalistic ideals, very often his Europe seems to be limited to France and to Germany. ${ }^{5}$ But the familiar problem with Platonist politics is: either it is never instantiated in reality, or it is all too easy to identify it with a specific reality which does not share the properties of the universal. If the former, it is not clear that embracing the European ideal is by itself a sign of moral progress. Sometimes Benda seems to speak as if the clerks' conversion to reason and to the universalist ideal is enough to realize this ideal in reality. At other places, he suggests, more sensibly, that intellectual conversion to the European Idea is but a prerequisite to the advent of European institutions. But he never cares to tell us what these institutions might be. ${ }^{6}$ In other words, one agrees with Benda about Platonist politics rather in the same way that one agrees with G.H. Hardy's defence of mathematical Platonism in A Mathematician's Apology: that it is basically a sound view, which everyone is willing to accept, but that one does not know how to implement.

In spite and in fact perhaps because of these ambiguities, it is still important to read Benda's Discourse today, since the tensions present in his positions are still with us. ${ }^{7}$ His abstract rationalism and his voluntaristic conception of Europe might be welcomed by writers who, like Habermas, have advocated a "post-nationalist" citizenship, ${ }^{8}$ but they would be baffled by his appeal to a European nation and by its implicit incarnation in the French conception of reason. His defence of the identity of Europe based on moral and intellectual values derived from Christian universalism would meet with agreement from those who insist that Europe owes its identity to Christianity (and in particular to Catholic Christianity), but they would be baffled by his claim that "Even an 
impious Europe will necessarily be less impious than the nation."9 Benda's position has also often been compared to the view of the French Republican nationalists. But these too would balk at his antinationalism and by what would be today called his anticommunitarianism.

In fact, however, the importance of Benda's Discourse resides not in the echoes now evoked by his own hesitations about the nature of European identity or about the best polity for unifying Europe. It resides rather in those of his views which seem to us the most old-fashioned: his distinctive and most uncontemporary conception of the moral and intellectual forces which have to shape common life; his belief in a class of learned 'clerks' who would have interiorised this conception and are ready to bring it to the masses through some sort of mystique. His simplistic dualisms of reason and passion, of particularity and universality, of temporality and eternity, his emphasis on the importance of the intellect, his uncompromising defence of pure learning and of the search after truth seem to us completely outlandish. But are they really so?

Benda obviously believed that Europe has a cultural unity, which he associated, correctly, with its Christian heritage. But he never meant to make culture the unifying element of Europe. For him, culture was associated with Kultur and with German nationalism. Today's debates are dominated on the one hand, by the opposition between uni-culturalists, who intend to identify Europe with a version of its cultural past, most often Christianity; and multiculturalists, who transpose an American debate into a European one, and maintain that the proper model has to be that of a 'multicultural citizenship';10 and, on the other hand, by the opposition between a European welfare state which reduces democracy to the implementation of the rules of equality, and a Europe of the nations where everyone feels at home. Indeed, Benda's Discours could, as I have suggested, be called in aid by both camps. But he also gives us some clues to help us overcome these oppositions. Because he was an uncompromising universalist, he would have pointed out the relativistic premises of the debates about 'multiculturalism', which appear in many ways to be a sort of compromise with relativism. Even if it were true that the EU, like the US, has become a multicultural space, it is not clear that its political unity owes anything to this feature.

Are today's 'clerks' so different from those whom Benda attacked? His targets were Barrès, Maurras, and on the German side Fichte, Hegel, and Marx (at a time when Hegelianism was making its entrance in France). 
But when one reads under the pen of Jürgen Habermas and Jacques Derrida that when the Iraq war burst out, "The power of feeling (die Macht der Gefühle) brought European citizens to their feet," and when Derrida tells us that Geist necessarily means something different from esprit, one gets the impression that the appeal to passion against which Benda warned us has not lost its force. ${ }^{11} \mathrm{He}$ was right to warn us against these remnants of romanticism. When one learns from Alain Badiou, that

The [program of ] the French philosophical movement [since 1960] has been to turn philosophy into an active form of writing that would be the medium for the new subject. And by the same token, to banish the meditative or professorial image of the philosopher; to make the philosopher something other than a sage, and so other than a rival to the priest ${ }^{12}$

and when the same writer tells us that the "identity" of French philosophy is but the expression of a "desire," what is exactly the difference, in spite of Badiou's Marxist program, between this emotional defence of French thought and the one that Barrès and Maurras once proposed? One feels that Benda's attack on nationalist clerks has to be done over and over again.

Benda's Europe is meant to be serious and even boring:

Europe will be serious or will not be. It will be much less 'entertaining' than the nations, which were also less so than the province. One will have to choose: either to make Europe or to keep on being children. [...] Europe will be more scientific than literary, more intellectual than artistic, more philosophical than picturesque. And for many of you this teaching will be cruel. (Discourse p. 51)

On Benda's view, this meant that the institutions of learning, and in particular the universities, have a prominent role. Has Benda's injunction been heard? The EU has put a lot of money into scientific research and has launched ambitious university programs, such as Erasmus and the "Bologna process." Would not Benda applaud the pronouncements of EU officials concerning the 'society of knowledge'? But he would also notice that academic clerks are everywhere less influential. The Humboldtian model of the university-a product of the nation state which combines Lehre and Forschung - is everywhere threatened, and the institutional setups favoured by the Bologna process tend to increase the separation between teaching and research. More and more universities look like Gymnasien or 
Hochschulen. This is the triumph of the pragmatic. Academics, everywhere, are treated like children.

So in the end, Europe has still a long way to go to get rid of the nation.

Pascal Engel

University of Geneva

\section{Notes}

1. Paris: Gallimard, 1933, Folio Gallimard (quoted after the revised edition of 1979). The best account of Benda's literary career is Antoine Compagnon, Les antimodernes, Paris: Gallimard, 2005.

2. La trahison des clercs, Paris: Grasset 1927, translated into English as The Treason of the Intellectuals, Beacon Press, 1928, new edition, with an introduction by Roger Kimball, New Brunswick: Transaction Publishers, 2006.

3. I have examined Benda's criticism of 'dynamism' in "Benda contre Bergson," Critique, No. 737, pp. 384-97.

4. This was noted by Michael Walzer, The Company of Critics, Social Criticism and Political Commitment in the Twentieth Century, London: Halaban, 1988, p. 29.

5. Actually in the only passage where he deals with the limits of Europe, he quotes the historian Ferdinand Lot: "It is thanks to the immolation of the 'Balkanics' and of the Eastern Slavonics that occidental civilisation could be furthered in occidental Europe" (Discours, p. 133).

6. Actually Benda had a much less irenic and more realistic approach to politics when he was confronted during the war with what he called "the great trial of democracy"; see his book La grande épreuve des démocraties, New York: Editions de la Maison française, 1942. On this book, and on Benda'activities during the war, see G. Malkassian, "Benda pendant l'occupation: la démocratie à l'épreuve," Revue philosophique, 127, 3, 2002, pp. 333-43.

7. For an excellent account of these, see Jan Werner Müller, "Julien Benda's anti-passionate Europe," European Journal of Political Theory, 5, 2, 2006, 125-37.

8. Habermas, Die postnationale Konstellation, Frankfurt: Suhrkamp, 1998, Jean Marc Ferry, La Question de l'État européen, Paris: Éditions Gallimard, Collection 'NRFessais," Paris, 2000.

9. See Remi Brague, Europe, la voie romaine, Critérion 1992, 2nd ed. Folio Gallimard 1999, translated as Eccentric Culture: A Theory of Western Civilisation, South Bend, Indiana: St. Augustine Press, 2002; Pierre Manent, L'Europe des nations, Paris: Gallimard 2006.

10. See for instance the proceedings of a conference held in the Sorbonne in 2002, La république ou l'Europe?, ed. P. Savidan, Paris: Hachette, 2004.

11. Jurgen Habermas and Jacques Derrida "Nach dem Krieg: Die Wiedergeburt Europas," Frankfurter Allgemeine Zeitung, 31 May 2003. Derrida, De l'esprit, Paris: Galilee, 1990. See also the Vocabulaire des philosophies européennes, ed. B. Cassin, Paris: Seuil 2004, where this kind of relativism receives the imprimatur of the European clerks.

12. Alain Badiou, "The Adventure of French Philosophy," New Left Review 35, September-October 2005. 